\title{
Representations of the origin of the universe in ancient and centrasiatic mythology
}

\author{
${ }^{1}$ Researcher, Uzbekistan.
}

\author{
Musurmanov Erkin ${ }^{1}$
}

Email:_musurmanov_e@umail.uz

\begin{abstract}
This article discusses the interpretation of the main gods of the Uzbek (Turkic) and Chinese mythology, their similar and distinctive features. Comparing the deities of Chinese mythology Pangu and Uzbek mythology Tengri, as well as the goddesses of Chinese and Uzbek mythology Nyuva and Umai, it is concluded that there is the unity of the genesis of the main gods of the pantheon of mythology of the two peoples.
\end{abstract}

Keywords: Central Asian mythology, first egg, Pangu and Tengri, Umai and Nyuva, their similarity and difference.

\section{INTRODUCTION}

The main gods in Chinese and ancient Uzbek (Turkic) myths, their creation, there are certain similarities in their activities in the creation of the universe and man. The first material matter was the secular egg, the first creator-man: Pangu in Chinese mythology, Tengri's tearing out of the egg in Turkish mythology, the activities of both in the creation of being; secondary female goddesses: the creative and patronage functions of Nyuyva and Umayyad; the third world - the images of the rulers of the underground kingdom Xi Wanmu and Erlik's activities in their own worlds are an example of this.

According to Xu Zheng (3rd century) in the San u li tzu (Chronological Records of Three Rulers and Five Emperors), "In ancient times, in the Pacific region, the universe consisted of darkness reminiscent of a large egg. In that world a great hero named Pangu is born. Pangu slept inside the egg for eighteen thousand years and finally woke up. When he opened his eyes, there was still darkness all around. He tried to break the egg with his body, but the egg was too firm ... Then he began to chop the darkness in front of his eyes with an ax. From the blow of his ax, a rumbling sound is heard, and this dark-covered egg cracks. All light and pure things will rise and the sky will appear ... "(1:58).

\section{MAIN PART}

We enrich the myth of Pangu with additions: "From Pangu's breath came wind and rain, from his breath came lightning and thunder, and when he opened his eyes, it was day, and when he closed it, it was night. Eighteen thousand years later, the sky and the earth froze and stopped growing, and Pangu died. His left eye is the sun, his right eye is the moon; elbows, knees, and head - five dead mountains; the body is the four sides of the universe; blood - river; roots - roads, hair - grass, flowers and trees; his teeth and bones were metal and precious stones, his skin was rain and dew, and the insects on his body were people. " $(2 ; 20)$

According to the Turkish myth associated with the egg and the creator, in ancient times there was a dead sea with neither blue nor earth. Inside, the White Light appeared. From it came a glowing egg. He had no limbs, no head, but movement; it had no wings, it flew, it had no mouth but it had a voice. Tengri, the creator of mankind, was asleep in it for a long time, and when he awoke, he could not find a way out of the egg. Inside he found only a steel hammer and spear. With their help, he cracked the egg and went outside. From the top of the egg, a blue sky was created, and from the bottom, a brown earth.

The famous Chinese mythologist Yuan Ke connects the image of Pangu with Panhu, known as the ancestor of the Myao and Yao peoples, and calls him Pangu. (4; 7) recorded. The five colors of the pangu-dog are reminiscent of the myth of Nyuyva, the goddess in Chinese folklore, who used a mixture 
of five colored stones to patch a cracked sky. The myth of the collapse of the sky is also present in Turkish mythology, and the injury of the sky was the cause of a quarrel between the dead, as in the myth of Nuywa. "Finally, Angur and Tangur sided. The two of them took long sticks in their hands, shook each other, and chased and chased from one end of the world to the other. The sticks of Angur and Tangur were stuck in the sky every time they fell, and the sky was cracked and cracked. The so-called Milky Way in the sky actually appeared when Angur and Tangur were on the same side. Then the god grabbed Angur and Tangur and said, "Do you want to destroy my sky ?!" He drowned them in the sea. $(6 ; 5)$

The number five actually represents the five main elements in the universe in Chinese mythology: iron, water, fire, earth, and wood. The fact that the Pangu-dog and the Nuywa stones are in five colors is also a hint of the participation of these five elements in the creation of the universe. The five-element basis later led to the creation of the "five" series of works in Chinese literature. The "Five Books" (Wǔjīng) tradition initiated by Confucius is one of the five great novels in Chinese literature ( 1 . The Three Kingdoms (Sānguó yănyì, XIV century) 2. The "Uzan Islands" (shuǐ hŭ zhuàn, 15th century) 3. "Journey to the West" Xīóuji, XVI century) 4. "Dream in the Red Palace" (hónglóumèng, XVIII century) 5. "Flowers in the Mirror" (hu hu, 1825) was introduced in China. The study of Alisher Navoi's connection with the tradition of writing "Khamsa", further enriched with the concept of "Chinese country", may reveal interesting information.

The image of the dog, both creative and prophetic, mentioned in Chinese mythology, is in many ways reminiscent of the image of the divine wolf in the mythology of the ancient Turks. There are legends that the Ashin dynasty considered themselves to be descended from wolves. $(6 ; 366-369)$ The image of Boybori in Alpomish, Boyborak in Korkut ota kitabi, and wolf in Oguznoma are the expressions of ancient beliefs. The ancient Turan, whose flags depicted the head of a wolf, was called the Saks or Shakes, and some took the image of the wolf in the flag as a dog. The golden-headed image of the Turkish totem wolf was depicted on the flags of the Turkish khans. The Khagans even called their bodyguards "wolves." (7; 126)

The great sinologist Bichurin N. Ya. The legend quoted by (Iakinf) also helps to clarify this issue: “... It is said that in the family of Hunn Shanyuyi (Mangu Hakan-M.E.), Two girls of unparalleled beauty came to Ochin. The maids knew them to be gods. Shanyu said: Do I give my daughters to people like that? I give them to the desire of the blue (heaven)... The sister disobeyed him and went down to the wolf, became his wife and gave birth to a son. From it the children multiplied and the state was created: therefore the people of this land love long songs, or howl like wolves. "( $8 ; 220)$

The genesis of a similar plot about the egg of the universe in Chinese and Turkish myths has much in common with the complex similarities in the myths of other peoples. The character of Russian fairy tales, according to some interpretations, the soul of the Immortal Kashchei, who has Turkish roots, is hidden in a magic egg. To kill him completely, Kashey dies only if he finds that egg, breaks it, and breaks the needle inside.

Ancient Chinese philosophers, such as Confucius and Menzies, left no information about Pangu. Our observations most likely lead to the conclusion that the myth of Pangu originated on the basis of Tengri-related concepts in Turkish mythology.

Umay, the female goddess in Turkish mythology, also has a variant in Chinese mythology. S. M. According to Abramzon, the genesis of the image of the legendary bird Humo, found in Persian and Arabic folklore, is connected with the image of Umay, one of the main creators in the mythology of the Turkic peoples $(9 ;$ p. 342). The variant of the goddess Umayyad in Chinese mythology is the goddess Nuywa.

Ancient Turan - Tengri - Pangu in Chinese mythology; The genesis of the Umayyad-Nuyva images is the same, but as a result of national identity, national mentality and various historical and social factors, they have changed from their original primitive imaginations and in parallel underwent an evolutionary process in some forms.

Certain parallels can also be drawn between the goddess Umayyad and a similar concept in other nations. The mother of the Buddha (Siddhartha Gautama) - Maya, the mother of Jesus Christ - Mary, the wife of Zeus and the mother of Hermes - the goddess Maya, the Aztec goddess of fertility - the image of Umayyad, which has a creative character in the mythology of our ancient ancestors. The image of the 
chief goddess Nyuyva Umay, who created man in Chinese folklore, is particularly close in every way. In addition to the similarity in their naming, they are also the same in the tasks assigned to them.

The goddess Nyuyva, a product of pure Chinese folklore, is depicted in Le-tszi (Lièž) with Fusi in the form of a snake's body, a cattle's head, a tiger's beak and a human face. There are concepts typical of Turkish folklore in the image of Newway. According to pre-Islamic views, the snake was considered sacred, a totem that bestowed goodness, prosperity, and wealth.

The concept of mythological woman-goddesses has existed among our people since ancient times, and their images are reflected in the archeological finds of the past.

The roots of the snake cult, a symbol of productivity and fertility in southern Turkmenistan, date back to the Eneolithic period. In the fourth millennium BC, the image of snakes is found in ancient jugs; and the image of the divine woman, the serpent, existed in the third millennium BC. This period also includes an image in the Golden Hill jar depicting a woman in direct contact with a snake (10, 35-40). Images of dragons, snakes mixed with humans and animals can be found in the Murgab seals and talismans of the Bronze Age $(11,224)$.

\section{CONCLUSION}

"Interest in snake cult in ancient Central Asia began after the discovery of stone snake statues in Fergana (Sokh village") $(12,18)$. G. When Castane announced the statues in 1913, he first tried to unravel the semantic aspects of the snake cult in Central Asia based on the myths of the peoples of the world. He explained that the two-headed, spotted serpent statue found in the early twentieth century was associated with the custom of offilation (sacrifice to the serpent) $(13,17-20) .1956$ Voronets M.E. tried to interpret this zoomorphic symbol based on Central Asian sources $(14,48)$.

The mythological views of our ancient ancestors influenced the religious, philosophical and artistic ideas of the region, including the spiritual and artistic worldview of the peoples of the present-day PRC.

\section{REFERENCES}

1. Мусурманов Э. Р, Ма Цуи Линг (马翠玲, 国家公派汉语教师). Хитой фольклори (афсона ва эртаклар): ўкув-услубий кўлланма. - Самарқанд: 2014.

2. Юань Кэ. Мифы Древнего Китая: Наука; Москва; 1965.

3. Жетписбаева Б.А. Древнетюркская литература. - Алматы, 2001.

4. Юань Кэ Мифы древнего Китая. Глава I. Введение. http://dragonsnest.ru/dragons/mythology/china/yuan_ke_mify_drevnego_kitaya_glava_i_vvedenie.php

5. Folklore archive at the Institute of Language and Literature named after Alisher Navoi of the Academy of Sciences of the Republic of Uzbekistan. Inv.№1477 / 5. Recorded on December 21, 1958 by Rahmatullah Yusuf oglu

6. Kjyashtorny S.G. The Royal Clan of the Turks and the Problem of its Designation//Post-Soviet Central Asia. Edited by Touraj Atabaki and John O'Kane. Tauris Academic Studies. London*New York in association with IIAS. The international Institute for Asian Studies. Leiden-Amsterdam.

7. S.G. Klyashtorny, V.A. Livshits. Sogdian inscription from Bugut. // Countries and peoples of the East, vol. H. 1971

8. Bichurin [Iakinf] N. Ya. Collection of information about the peoples who lived in Central Asia in ancient times. ML USSR Academy of Sciences, Institute of Ethnography Miklouho-Maclay. 1950

9. Cheremisin D. V. On the study of Iranian-Turkic relations in the field of mythology // Natives of Siberia: problems of the study of endangered languages and cultures: Tez. doc. Int. scientific conf. - Novosibirsk: RAS SB, Institute of Philology, Institute of History and Archeology, 1995. T. 1.

10. Kozhin P.M., Sarianidi V.I. The snake in the cult symbolism of the Anau tribes. - In the book: History, Archeology and Ethnography of Central Asia. M .: Nauka, 1968. 
11. Sarianidi V.J. Seal Amulets of the Murghab Style. — In: The Bronze Age Civilizating of Central Asia. Recent Soviet Discoveries / Ed. with an introduction by Kohl Philip. N.Y., 1981.

12. Belenitsky A.M., Meshkeris V.A. Dragon snakes in the ancient art of Central Asia. // "Soviet archeology". 1986. No. 3. -WITH. 16-27.

13. Castan G. The cult of snakes in various nations and its traces in Turkestan. - PTKLA. Year seventeen. Tashkent, 1913.-S. 17-24.

14. Voronets M.E. Stone image of snakes from the village of Sokh, Ferghana region. - Brief communications from the Institute of the History of Material Culture. 1956, no. 61. 